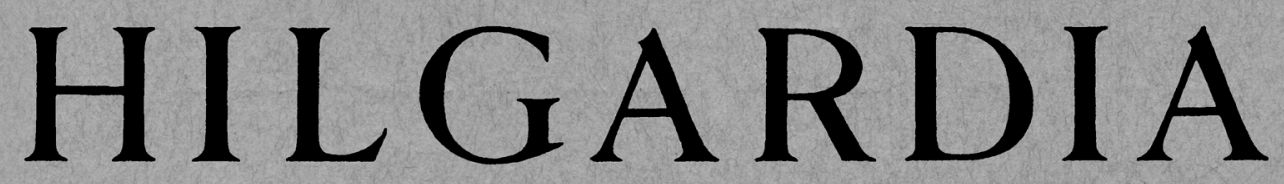

A Journal of Agricultural Science Published by the California Agricultural Experiment Station

\title{
CONTENTS
}

INSECT TRANSMISSION, HOST RANGE, AND PROPERTIES OF THE CRINKLE-LEAF STRAIN OF WESTERN-CELERY-MOSAIC VIRUS

JULIUS H. FREITAG and HENRY H. P. SEVERIN

TRANSMISSION OF CELERY-YELLOW-SPOT VIRUS BY THE HONEYSUCKLE APHID, RHOPALOSIPHUM CONII (DVD.)

JULIUS H. FREITAG and HENRY H. P. SEVERIN

POISON-HEMLOCK-RINGSPOT VIRUS AND ITS TRANSMISSION BY APHIDS TO CELERY

JULIUS H. FREITAG and HENRY H. P. SEVERIN

UNIVERSITY OF CALIFORNIA · BERKELEY, CALIFORNIA 


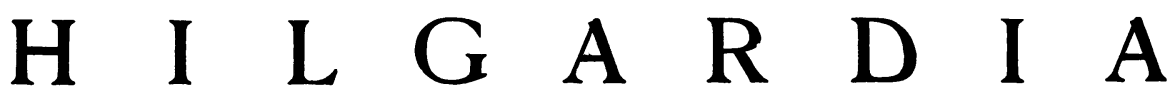 \\ A Journal of Agricultural Science Published by \\ the California Agricultural Experiment Station
}

VoL. 16.

MARCH, 1945

No. 8

\section{INSECT TRANSMISSION, HOST RANGE, AND PROPERTIES OF THE CRINKLE-LEAF STRAIN OF WESTERN-CELERY-MOSAIC VIRUS ${ }^{1}$}

\author{
JULIUS H. FREITAG ${ }^{2}$ AND HENRY H. P. SEVERIN ${ }^{3}$
}

IN THE last five years several viroses affecting celery have been observed to occur naturally in California. These, except western celery mosaic, have been only briefly described in previous papers (Freitag and Severin, 1939; Severin and Freitag, 1938). A mosaic disease apparently different from western celery mosaic was first observed near Milpitas in the Santa Clara Valley during November, 1937. The symptoms resemble those of western celery mosaic except that the leaves are, as a rule, severely crinkled. The disease is not common and has been found only rarely during routine observation of celery fields.

An investigation was undertaken to determine the symptoms, properties, and host range; likewise, the relative ability of various aphid species that breed on celery to transmit the virus. Aphids were compared with mechanical inoculation as a means of transmitting the virus. The retention of the virus by three species of aphids was studied experimentally.

\section{MATERIALS AND METHODS}

The virus was obtained from a naturally infected celery plant collected at Milpitas. A continuous supply was maintained in the greenhouse through repeated mechanical inoculation of healthy celery plants by the carborundum method described by Rawlins and Tompkins (1936).

The general methods employed in these studies resemble those described earlier (Severin and Freitag, 1938). The aphid species used were maintained, with two exceptions, on celery in the greenhouse. The green peach aphid, Myzus persicae (Sulzer), was reared on sugar bets; and the potato aphid, Macrosiphum solanifolii (Ashm.), on squash. The experiments performed were carried out under greenhouse conditions at Berkeley.

\section{SYMPTOMS}

The first symptom of the mosaic virus to develop is a clearing of the veins and veinlets on the youngest leaves of infected celery plants about 10 days

${ }^{1}$ Received for publication March 7, 1944.

${ }^{2}$ Assistant Professor of Entomology and Assistant Entomologist in the Experiment Station.

${ }^{3}$ Entomologist in the Experiment Station.

"See "Literature Cited" for complete data on citations, referred to in the text by author and date of publication. 
after inoculation. This is followed by a conspicuous yellow vein banding, with green interveinal areas (plate $1, A$ ). The yellow bands are at first narrow (plate $1, A$ ), but gradually become broader (plate $1, B$ ) and diffuse in outline (plate $1, C$ ). The vein clearing and vein banding are often limited to the basal portion of leaflets (plate $1, C$ ), though the entire leaflet may be affected (plate $1, B$ ). The interveinal areas become chlorotic; they gradually coalesce with the yellow vein banding to form enlarged amber-yellow areas (plate 1, $D$ ) somewhat resembling celery-calico symptoms (Severin and Freitag, 1938).

The most conspicuous symptoms of the disease are the crinkling of the leaflets and the raised green islands or blisterlike elevations (plate $1, E, F$ ) within chlorotic areas. The elevations, irregular in shape and size, are often located in the tissue between yellowed veins. The youngest leaves of infected plants develop a downward or upward curl of the leaf margin (plate 1, $F$ ); the result is a pronounced crinkling.

Young plants experimentally infected with the virus in the greenhouse are stunted. In the later stages of the disease they become chlorotic and frequently die as a result of infection.

\section{HOST RANGE}

Experimental Infection.-Young seedlings of the various plants tested were mechanically inoculated with the virus in the greenhouse. Besides celery (Apium graveolens L. var. dulce DC.) the following plants, all members of the family Umbelliferae, proved susceptible to the virus :

Large Smooth Prague celeriac, Apium graveolens L. var. rapaceum DC.

Dill, Anethum graveolens L.

Salad chervil, Anthriscus Cerefolium Hoffm.

Caraway, Carum Carvi L.

Coriander, Coriandrum sativum $\mathrm{L}$.

Carrot, Daucus Carota L. var. sativa DC.

White varieties: Short White, White Belgian

Yellow variety: Yellow Belgian

Orange varieties: Chantenay, Chantenay Red Cored, Danvers, Early Scarlet Horn, Imperator, and Long Orange

Long Smooth parsnip, Pastinaca sativa L.

Single, or Plain, parsley, Petroselinum crispum Nym. var. latifolium

Anise, Pimpinella Anisum L.

Recovery of Virus.-From all the experimentally infected plants listed above the virus was recovered by extracting juice and inoculating it into healthy celery plants.

Symptoms.-Vein clearing and mottling usually developed as a result of infection. On some plants, chlorotic streaks along the veins and crinkling of the leaves also occurred.

Infection of salad chervil was indicated by stunted chlorotic leaflets with downward-cupped youngest leaves. Brown, sunken necrotic streaks and areas developed along the petioles, followed by marked necrotic lesions on infected leaves.

Carrots were, as a rule, only mildly affected; the symptoms were often indistinct. A few plants, however, showed definite symptoms. First, after 
inoculation, the veins cleared; then chlorotic spotting and streaking appeared along them. The irregular chlorotic areas on the leaflets and the sunken dark brown areas on the petioles became necrotic. Infected carrots were often dwarfed and had curled, malformed, dwarfed leaves.

Plants That Failed to Develop Infection.-The following plants, when inoculated with juice from infected celery, failed to develop infection under greenhouse conditions. An attempt was made to recover the virus from all inoculated plants even though they failed to develop symptoms.

Chenopodiaceae

Sugar beet, Beta vulgaris L.

Long Standing Bloomsdale spinach, Spinacia oleracea L. var. inermis Peterm.

Compositae

Lemon King calendula or pot-marigold, Calendula officinalis $\mathrm{L}$.

Whitloof chicory, Cichorium Intybus L.

Orange African daisy, Dimorphotheca aurantiaca DC.

New York lettuce, Lactuca sativa L. var. capitata Hort.

Giant White and Scarlet Gem zinnia, Zinnia elegans Jacq.

Cruciferae

February cauliflower, Brassica oleracea L. var. botrytis L.

Cucurbitaceae

Early White Spine cucumber, Cucumis sativus L.

Zucchini or Italian Marrow squash, Cucurbita pepo L.

Solanaceae

California Wonder pepper, Capsicum frutescens L. var. grossum Bailey

Jimson weed, Datura Stramonium L.

Marglobe tomato, Lycopersicon esculentum Mill. var. commune Bailey

Connecticut Seed Leaf, Havana, White Burley, and Turkish tobacco, Nicotiana

Tabacum L.

Nicotiana glutinosa $\mathrm{L}$.

Black Beauty and New York Improved Spineless eggplant, Solanum Melongena L. var. esculentum Nees

Sutton Flourball potato, Solanum tuberosum L.

Umbelliferae

Poison hemlock, Conium maculatum L.

Cow parsnip, Heracleum lanatum Michx.

\section{PROPERTY STUDIES OF VIRUS}

Experiments were undertaken to determine certain properties of the virusthermal inactivation, tolerance to dilution, longevity in vitro, and resistance to alcohol. The leaves of experimentally infected celery plants grown in the greenhouse were ground to a plup, and then the juice was expressed through cheesecloth. Five celery plants were inoculated with the juice of each preparation.

Thermal Inactivation.-Experiments to determine the thermal-inactivation temperature were carried out by pipetting $10 \mathrm{cc}$ of leaf juice from experimentally infected celery plants into thin-walled glass test tubes, which were then plugged with cotton. When the water bath had reached the desired temperature, the test tubes were immersed for 11 minutes; 1 minute was allowed for the juice to reach the temperature of the bath. The water was maintained within 1 degree of the desired temperature by turning the electric heating 
units on and off as necessary. To maintain a uniform temperature throughout the bath, the water was agitated and kept circulating by a stirring rod attached to an electric motor. After the 11 minutes, the test tubes were cooled in running tap water. The virus was tested at five different temperatures at 5-degree intervals, beginning at $45^{\circ} \mathrm{C}$.

TABLE 1

Thermal Inactivation of Celery Crinkle-Leaf-Mosaic Virus

\begin{tabular}{|c|c|c|c|}
\hline \multirow{2}{*}{ Temperature, ${ }^{\circ} \mathrm{C}$} & \multirow{2}{*}{$\begin{array}{l}\text { Number of } \\
\text { preparations } \\
\text { infectious } \\
\text { of } 7 \text { tested }\end{array}$} & \multicolumn{2}{|c|}{$\begin{array}{l}\text { Celery plants infected } \\
\text { of } 35 \text { inoculated }\end{array}$} \\
\hline & & Number & Per cent \\
\hline 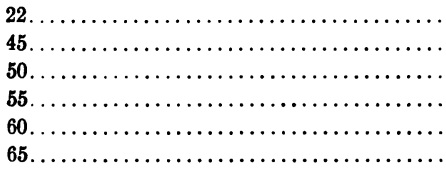 & $\begin{array}{l}7 \\
7 \\
4 \\
1 \\
0 \\
0\end{array}$ & $\begin{array}{r}32 \\
35 \\
5 \\
1 \\
0 \\
0\end{array}$ & $\begin{array}{r}91.4 \\
71.4 \\
14.3 \\
2.9 \\
0.0 \\
0.0\end{array}$ \\
\hline
\end{tabular}

Seven preparations were tested. According to the data in table 1, only one of these was still infectious when heated for 10 minutes at $55^{\circ} \mathrm{C}$, and no infection resulted from juice treated at $60^{\circ}$ and $65^{\circ}$. These results show that the virus is thermally inactivated between $55^{\circ}$ and $60^{\circ}$, though the greatest inactivation occurred between $45^{\circ}$ and $50^{\circ}$.

Tolerance to Dilution.-Eight separate preparations were made to test the tolerance of the virus to dilution. The results indicate a low concentration of

TABLE 2

Tolerance of Celery Crinkle-Leat-Mosaic Virus to Dilution

\begin{tabular}{|c|c|c|c|}
\hline \multirow{2}{*}{ Dilution } & \multirow{2}{*}{$\begin{array}{c}\text { Number of } \\
\text { preparations } \\
\text { infectious } \\
\text { of } 8 \text { tested }\end{array}$} & \multicolumn{2}{|c|}{$\begin{array}{l}\text { Celery plants infected } \\
\text { of } 40 \text { inoculated }\end{array}$} \\
\hline & & Number & Per cent \\
\hline Control. . & 8 & 32 & 80.0 \\
\hline $1: 10 \ldots \ldots$ & 8 & 31 & 77.5 \\
\hline $1: 100 \ldots$ & 5 & 8 & 20.0 \\
\hline $1: 1,000 \ldots$ & 0 & 0 & 0.0 \\
\hline $1: 10,000 \ldots$ & 0 & 0 & 0.0 \\
\hline $1: 100,000 \ldots$ & 0 & 0 & 0.0 \\
\hline
\end{tabular}

virus in the experimentally infected plants. As table 2 shows, the 1:10 dilutions were almost as effective as undiluted juice; but the $1: 100$ dilutions were only about one fourth as effective as the undiluted virus, and infections were obtained with only five of the eight preparations. No infections were obtained with the $1: 1,000$ or greater dilutions.

Tolerance to Aging in Vitro.-Experiments were conducted to determine the tolerance of the virus to aging in vitro. Ten cubic centimeters of juice extracted from the leaves of experimentally infected celery plants were placed in each test tube, which was plugged with cotton and stored at room temperature, about $22^{\circ} \mathrm{C}$. Seven separate preparations were inoculated daily for 7 
days after the extraction of the juice. Five celery plants were inoculated with each preparation each day.

The results (table 3 ) show that three preparations were still infectious on the third day, but that all seven were inactivated by the fourth day. The greatest inactivation occurred during the first 24 hours.

TABLE 3

Tolerance of Celery Crinkle-Leaf-Mosaic Virus to AGING in Vitro

\begin{tabular}{|c|c|c|c|}
\hline \multirow{2}{*}{ Days exposed } & \multirow{2}{*}{$\begin{array}{l}\text { Number of } \\
\text { preparations } \\
\text { infectious } \\
\text { of } 7 \text { tested }\end{array}$} & \multicolumn{2}{|c|}{$\begin{array}{l}\text { Celery plants infected } \\
\text { of } 35 \text { inoculated }\end{array}$} \\
\hline & & Number & Per cent \\
\hline 0 (control) $\ldots \ldots \ldots \ldots \ldots \ldots \ldots \ldots$ & 7 & 33 & 94.3 \\
\hline $1 \ldots \ldots \ldots \ldots \ldots \ldots \ldots \ldots \ldots \ldots \ldots \ldots$ & 2 & 6 & 17.1 \\
\hline 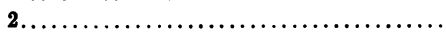 & 2 & 3 & 8.6 \\
\hline 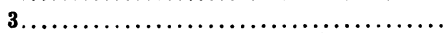 & 3 & $\mathbf{5}$ & 14.3 \\
\hline 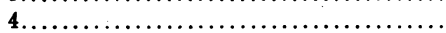 & 0 & 0 & 0.0 \\
\hline 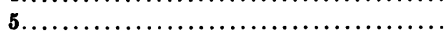 & 0 & $\mathbf{0}$ & 0.0 \\
\hline $6 \ldots \ldots \ldots \ldots \ldots \ldots \ldots \ldots \ldots \ldots \ldots \ldots \ldots$ & $\mathbf{0}$ & 0 & 0.0 \\
\hline 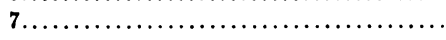 & 0 & $\mathbf{0}$ & 0.0 \\
\hline
\end{tabular}

Resistance to Alcohol Treatment.-Tests were made to determine the resistance of the virus to alcohol during 1-hour exposures. To juice extracted from experimentally infected celery plants, absolute alcohol was added in such quantities that resulting mixtures of $10,20,30,40$, and 50 per cent alcohol were obtained. These were allowed to stand for 1 hour. The precipi-

TABLE 4

Resistance of Cerert Crinkle-Leaf-Mosatc Virus Extract TO AlcoHol DURING ONe-Hour Exposures

\begin{tabular}{|c|c|c|c|c|c|c|}
\hline \multirow{3}{*}{ Per cent alcohol } & \multirow{2}{*}{\multicolumn{2}{|c|}{$\begin{array}{l}\text { Number of preparations } \\
\text { infectious of } 5 \text { tested }\end{array}$}} & \multicolumn{4}{|c|}{ Celery plants infected of 25 inoculated } \\
\hline & & & \multicolumn{2}{|c|}{ Number } & \multicolumn{2}{|c|}{ Per cent } \\
\hline & $\begin{array}{l}\text { Super- } \\
\text { natant } \\
\text { liquid }\end{array}$ & $\begin{array}{l}\text { Precipi- } \\
\text { tate* }\end{array}$ & $\begin{array}{l}\text { Super- } \\
\text { natant } \\
\text { liquid }\end{array}$ & $\underset{\text { tate }}{\text { Precipi- }}$ & $\begin{array}{l}\text { Super- } \\
\text { natant } \\
\text { liquidd }\end{array}$ & $\begin{array}{l}\text { Precipi- } \\
\text { tate }\end{array}$ \\
\hline 0 (control) $\ldots \ldots \ldots \ldots \ldots \ldots \ldots$ & 5 & $\mathbf{5}$ & 21 & 24 & 84 & 96 \\
\hline $10, \ldots \ldots \ldots \ldots \ldots \ldots \ldots \ldots \ldots \ldots \ldots$ & 1 & 5 & 2 & 22 & 8 & 88 \\
\hline 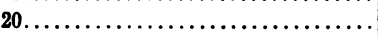 & 1 & 5 & 1 & 15 & 4 & 60 \\
\hline 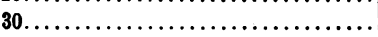 & 0 & 2 & 0 & 2 & 0 & 8 \\
\hline $40 \ldots \ldots \ldots \ldots \ldots \ldots \ldots \ldots \ldots$ & 0 & 0 & 0 & $\mathbf{0}$ & 0 & 0 \\
\hline $50 \ldots \ldots \ldots$ & 0 & 0 & 0 & $\mathbf{0}$ & 0 & 0 \\
\hline
\end{tabular}

- The control juice became turbid on standing; and on centrifugation a precipitate was separated, which was resuspended in distilled water.

tate that formed was separated from the rest of the mixture by centrifuging for 15 minutes at 3,500 revolutions per minute. The supernatant alcoholic solution was poured from the centrifuging tubes and inoculated into five healthy celery plants in each of five separate preparations. The precipitate was first washed in sterile distilled water, then resuspended in a quantity of distilled water equal to the original volume of the extracted celery juice, and 
finally used for inoculation. The control juice became turbid on standing; and on centrifugation a precipitate was separated, which was resuspended in distilled water.

As shown in table 4, the virus in the supernatant liquid was still active in 20 per cent alcohol in one of five preparations, but was inactivated in all preparations tested at 30 per cent alcohol. The virus in the precipitate was active in two of five preparations of 30 per cent alcohol, whereas all preparations tested at 40 per cent alcohol proved inactive. The virus in the supernatant liquid and that in the precipitate probably have the same resistance to alcohol. The fact that there is a higher concentration of the virus in the precipitate might account for the results.

\section{TABLE 5}

Transmission of Celery Crinkle-Leaf-Mosaic Virus by Mechanical INOCULATION, Compared WITH TRANSMISSION BY APHIDS*

\begin{tabular}{|c|c|c|c|c|c|c|}
\hline \multirow{3}{*}{ Aphid species } & \multicolumn{3}{|c|}{ Aphid transmission } & \multicolumn{3}{|c|}{ Mechanical inoculation } \\
\hline & \multirow{2}{*}{$\begin{array}{c}\text { Plants } \\
\text { inoculated }\end{array}$} & \multicolumn{2}{|c|}{ Plants infected } & \multirow{2}{*}{ inoculated } & \multicolumn{2}{|c|}{ Plants infected } \\
\hline & & Number & Per cent & & Number & Per cent \\
\hline Celery leaf aphid, Aphis a pigraveolens Essig.... & 25 & 1 & 4.0 & 25 & 21 & 84.0 \\
\hline Celery aphid, Aphis apii Theo................. & 25 & 0 & 0.0 & 25 & 17 & 68.0 \\
\hline \multicolumn{7}{|l|}{ Rusty-banded aphid, Aphis ferruginea-striata } \\
\hline 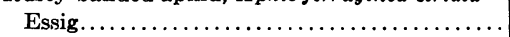 & 50 & 13 & 26.0 & 50 & 47 & 94.0 \\
\hline Cotton or melon aphid, A phis gossypii Glover. . & 25 & $\mathbf{0}$ & 0.0 & 25 & 19 & 76.0 \\
\hline Erigeron root aphid, Aphis middletonii Thos.... & 25 & $\mathbf{0}$ & 0.0 & 25 & 21 & 84.0 \\
\hline Yellow willow aphid, Cavariella capreae Fab...... & 25 & 0 & 0.0 & 25 & 19 & 72.0 \\
\hline Potato aphid, Macrosiphum solanifolii (Ashm.). & 10 & 0 & 0.0 & 10 & 10 & 100.0 \\
\hline Lily aphid, Myzus circumflexus (Buck.)......... & 25 & 3 & 12.0 & 25 & 23 & 92.0 \\
\hline Foxglove aphid, Myzus convolvuli (Kalt.)........ & 25 & 1 & 4.0 & 25 & 20 & 80.0 \\
\hline Green peach aphid, Myzus persicae (Sulzer)..... & 25 & $\mathbf{5}$ & 20.0 & 25 & 22 & 88.0 \\
\hline Honeysuckle aphid, Rhopalosiphum conii (Dvd.) & 35 & 1 & 2.9 & 35 & 31 & 88.6 \\
\hline Total or average.................. & .. & .. & .. & 295 & 250 & 84.7 \\
\hline
\end{tabular}

* The same experimentally infected plants were used as a source of virus for the aphid transmission and for the mechanical inoculation tests. Five healthy plants were inoculated from each infected plant by each method. Virus was recovered by mechanical inoculation from each previously infected plant.

\section{APHID TRANSMISSION OF VIRUS}

Comparison of Mechanical Inoculation with Aphid Transmission.-The transmission of the virus from experimentally infected to healthy celery by mechanical inoculation was compared with transmissions by various species of aphids. Ten species found to breed on celery under natural conditions in California, and the potato aphid, were tested for their ability to transmit the virus; these are listed in table 5. Five lots of twenty-five aphids each were transferred from each infected plant tested to five healthy celery plants, and the juice from the infected plant was then inoculated into another lot of five plants.

The results (table 5) indicate that aphids were less efficient than mechanical inoculations in transmitting the virus. Whereas five of the eleven species of aphids tested failed to transmit it, mechanical inoculations made with the juice from the infected plants on which the aphids had fed produced a high per- 
centage of infection. The rusty-banded aphid proved to be the most efficient vector, infecting 13 of 50 celery plants, or 26 per cent. Mechanical inoculations resulted in 250 infections of 295 celery plants inoculated, or $84.7 \mathrm{per}$ cent.

Retention of Virus by Aphids.-The three species of aphids demonstrated to be the most efficient vectors of the virus were tested to determine how long they retained the virus. They were bred on infected celery plants. Twentyfive from each infected plant were then transferred to each of five healthy celery plants and to successive healthy plants daily for 3 days. The aphids were confined on the third lot of celery for 1 week. Since a very low percentage of transmission of the virus was obtained, it was considered desirable to

TABLE 6

Retention of Celery Crinkle-Leaf-Mosaic Virus by Three Species of Aphids Transferred Daily to Three Successive Healthy Celery Plants

\begin{tabular}{|c|c|c|c|c|c|c|c|c|}
\hline \multirow[b]{2}{*}{ Aphid } & \multicolumn{5}{|c|}{ Aphid transmission } & \multicolumn{3}{|c|}{$\begin{array}{l}\text { Control tests by } \\
\text { mechanical inoculation }\end{array}$} \\
\hline & $\begin{array}{l}\text { Plants } \\
\text { inocu- } \\
\text { lated } \\
\text { daily }\end{array}$ & $\begin{array}{l}\text { Plants } \\
\text { infected } \\
\text { 1st day }\end{array}$ & $\begin{array}{l}\text { Per cent } \\
\text { infected } \\
\text { 1st day }\end{array}$ & $\begin{array}{l}\text { Plants } \\
\text { infected } \\
\text { 2d day }\end{array}$ & $\begin{array}{c}\text { Plants } \\
\text { infected } \\
3 \mathrm{~d} \text { to } \\
7 \mathrm{th} \text { day }\end{array}$ & $\begin{array}{l}\text { Plants } \\
\text { inocu- } \\
\text { lated }\end{array}$ & $\begin{array}{l}\text { Plants } \\
\text { infected }\end{array}$ & $\begin{array}{l}\text { Per cent } \\
\text { infected }\end{array}$ \\
\hline $\begin{array}{l}\text { Rusty-banded aphid, } \\
\text { Aphis ferruginea-striata } \\
\text { Essig. . . . . . . . . . }\end{array}$ & 45 & 4 & 8.9 & 0 & 0 & 45 & 39 & 86.7 \\
\hline $\begin{array}{r}\text { Lily aphid, Myzus circum- } \\
\text { flexus (Buck.)........... }\end{array}$ & 25 & 3 & 12.0 & 0 & 0 & 25 & 24 & 96.0 \\
\hline $\begin{array}{r}\text { Green peach aphid, } \text { Myzus } \\
\text { persicae (Sulzer)......... }\end{array}$ & 25 & 2 & 8.0 & 0 & 0 & 25 & 19 & 76.0 \\
\hline Total or average......... & .. & .. & . & .. & .. & 95 & 82 & 86.3 \\
\hline
\end{tabular}

demonstrate, by mechanical inoculation of juice into healthy plants, the presence of active virus in all celery used as a source of virus.

The results (table 6) demonstrate that of the three aphid species tested all failed to retain the virus for more than 1 day. The rusty-banded aphid infected 8.9 per cent of the celery plants, the green peach aphid 8.0 per cent, and the lily aphid 12.0 per cent, during the first day; but none of the three aphid species infected any plants thereafter. The infected plants on which the aphids were bred proved to be excellent sources of virus. Their juice, when mechanically inoculated into 95 celery plants, resulted in 82 infections, or 86.3 per cent.

\section{DISCUSSION}

Celery crinkle-leaf-mosaic virus is considered to be a strain of westerncelery-mosaic virus because of similarities of symptoms, host range, properties, and insect transmission. The results obtained with celery crinkle-leaf mosaic are compared with those previously described for western celery mosaic (Severin and Freitag, 1938). It differs in that it develops a yellow mottle with raised blister-like areas and a pronounced crinkling of the leaves, which readily distinguish it from western celery mosaic. The crinkle-leaf strain develops a more pronounced vein clearing and yellow vein banding. 
These are often confined to the basal portion of the leaflet, whereas the vein clearing of western celery mosaic usually extends over the entire leaf.

The host ranges of the two strains are apparently limited to plants of the family Umbelliferae. Crinkle-leaf strain was transmitted to Long Smooth parsnip and anise, two host plants to which the western-celery-mosaic virus was not transmitted. Additional inoculations with the latter virus will be necessary, however, before these two hosts can be considered immune to it. Carrot proved more susceptible to western celery mosaic.

The properties of the two viruses may be summarized as follows:

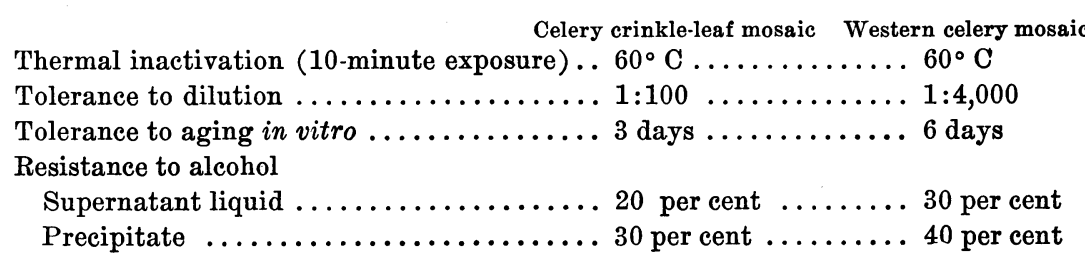

Transmission of the crinkle-leaf strain by the extracted juice from experimentally infected plants has given a uniformly high percentage of infection. As a rule, the western-celery-mosaic virus was just as readily transmitted; but in certain instances the percentage of 'plants infected dropped to less than 50 per cent.

Aphids proved inefficient as vectors of the crinkle-leaf strain. Five of eleven species tested failed to transmit the virus, while the six species that were successful infected only 4 to 26 per cent of the celery plants on which they fed. Western-celery-mosaic virus was readily transmitted by all the aphid species tested. The six species known to breed on celery and proved to be capable of transmitting both viruses were more efficient for the western celery mosaic, infecting 53 to 92 per cent of the plants on which they fed.

${ }^{5}$ Data from Severin and Freitag, 1938. 


\section{SUMMARY}

The host range of celery crinkle-leaf-mosaic virus is limited to plants belonging to the family Umbelliferae. The following have been experimentally infected: celery, Apium graveolens L. var. dulce DC. ; Large Smooth Prague celeriac, Apium graveolens L. var. rapaceum DC.; dill, Anethum graveolens L. ; salad chervil, Anthriscus Cerefolium Hoffm. ; caraway, Carum Carvi L.; coriander, Coriandrum sativum L.; Long Smooth parsnip, Pastinaca sativa L.; Single, or Plain, parsley, Petroselinum crispum Nym. var. latifolium; anise, Pimpinella Anisum L.; and nine varieties of carrot, Daucus Carota L. var. sativa DC.

Symptoms of celery crinkle-leaf-mosaic virus consist of yellow mottling, leaf crinkling, raised blisterlike areas, and a pronounced vein clearing.

The properties of the virus were found to be as follows: The thermal inactivation is $60^{\circ} \mathrm{C}$ in 10-minute exposures. The tolerance to dilution is $1: 100$. The virus remains active in extracted celery juice kept in a test tube at room temperature for 3 days. It is not completely inactivated in the supernatant liquid of a 20 per cent alcohol mixture nor in the precipitate of a 30 per cent alcohol mixture during 1-hour exposures.

The virus was more readily transmitted by mechanical inoculation than by aphid vectors. Mechanical inoculations of extracted celery juice produced infection in 84.7 per cent of the celery plants inoculated. Only 6 of 11 species of aphids tested proved capable of transmitting the virus, and these infected only 8.1 per cent of the plants inoculated.

Three species of aphids retained the virus the first 24 hours, but failed to infect a second lot of plants the next day or a third lot the following week.

Results of studies of host ranges, properties, and transmission of viruses by aphids and mechanical inoculation indicate that celery crinkle-leaf mosaic is a strain of western-celery-mosaic virus. 


\section{LITERATURE CITED}

Freitag, J. H., and H. H. P. Severin.

1939. Additional celery viroses. (Abstract.) Phytopathology 29 : 824.

RAwlins, T. E., and C. M. Tompkins.

1936. Studies on the effect of carborundum as an abrasive in plant virus inoculations. Phytopathology $26: 578-87$.

Severin, H. H. P., and J. H. Freitag.

1938. Western celery mosaic. Hilgardia $11(9): 493-558$. 

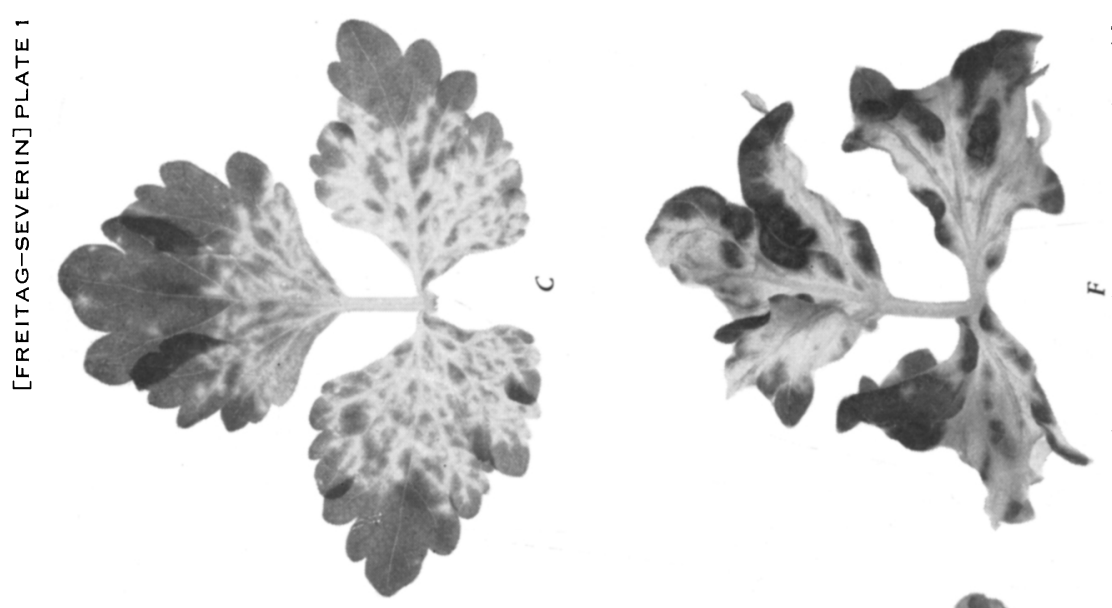

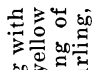

6ot.

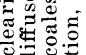

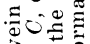

$-7 \bar{w}$

和影

.

(5)

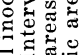

ฮ.

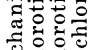

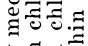

B.도유.

政

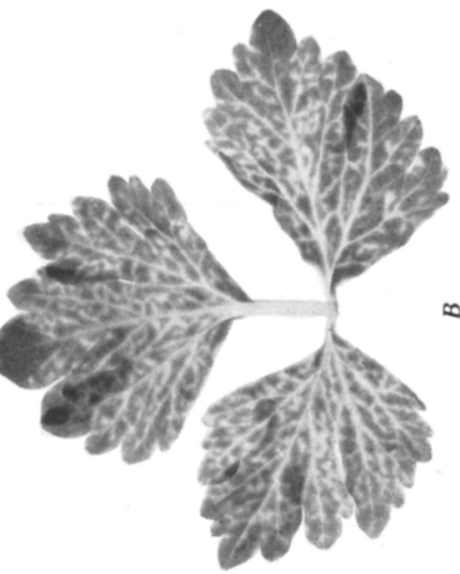

$\infty$

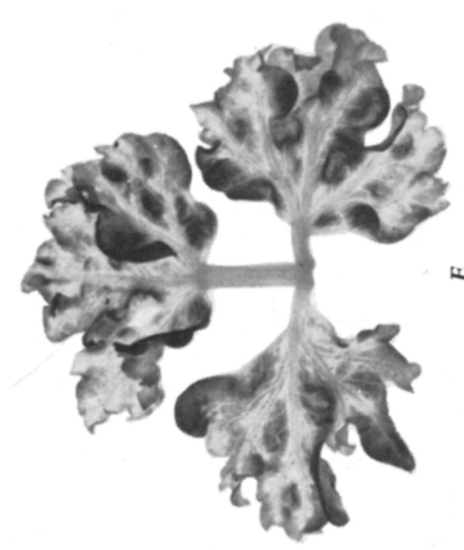

.

$\exists \approx$

ब.

$\Rightarrow$

政

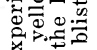

iٓ

कू 50

출

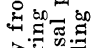

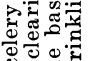

एँ

०ै ₹

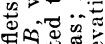

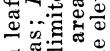

형
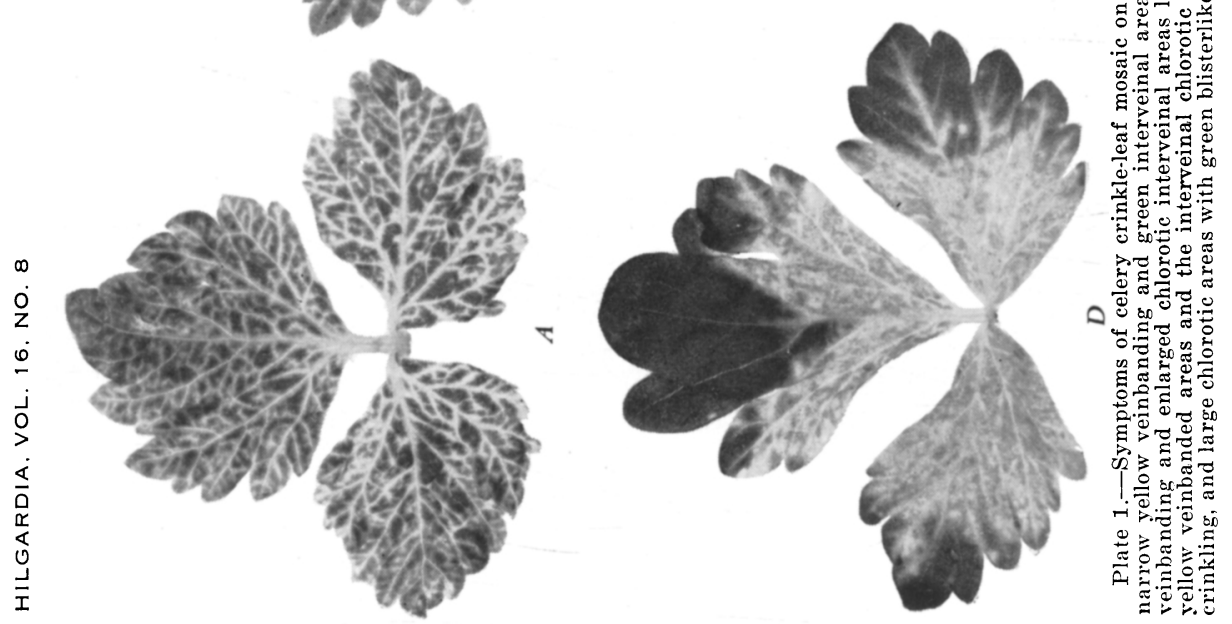